\title{
DNA hazard in Furnace Operating Workers from a Power Plant
}

\author{
Kır T11, Durmaz E², Ulutas $\mathrm{OK}^{2}$, Cok $\mathrm{I}^{2}$ and Donbak $\mathrm{L}^{1 *}$ \\ ${ }^{1}$ Kahramanmaras Sutçu Imam University, Science and Arts Faculty, Department of Biology, Kahramanmaras, Turkey \\ ${ }^{2}$ Gazi Universities, Faculty of Pharmacy, Department of Toxicology, Ankara, Turkey
}

\begin{abstract}
The aim of this study was to investigate the possible DNA damage in workers occupationally exposed to coal combustion products in furnace section of Afsin-Elbistan A power plant (Turkey). With this purpose, venous blood samples collected from 36 male power plant workers were analysed by comet assay for determining the level of DNA tail intensity. The obtained results were compared with those of control group consisting of 34 healthy male individuals. The data comparison showed that mean frequency of tail intensity was significantly higher in workers as compared to control group $(P<0.05)$, respectively $9.94 \pm 2.51$ and $8.48 \pm 2.31$. Present study indicated the DNA damage in the peripheral lymphocytes of furnace operators, possibly due to the several chemical compounds present in the coal ash and gaseous emissions.
\end{abstract}

Keywords: Coal fired power plant; Afsin-Elbistan A; Power plant workers; Genotoxic risk; Comet assay

\section{Introduction}

Thermal power plants leads to the emission of significant amounts of $\mathrm{SO}_{2}$ and fine particulate matter, volatile organic compounds (VOCs) and toxic organic micro pollutants, such as polycyclic aromatic hydrocarbons (PAHs) into the environment $[1,2]$. These products of combustion represent a risk to both environment [3,4] and human $[5,6]$. Considering increased coal production and utilization, several researchers concerned with the safety and health of the workers who utilize coal and expose to coal combustion products in various workplace. Epidemiological studies have shown that exposure to PAHs is associated with time- and dose-dependent increases in risk of cancer namely lung, colon, and bladder, and adverse birth outcomes [7-9]. Beside, other concents of coal combustion products such as coal ash, quartz, carbon, nitrogen, and sulfir oxides, and trace elements have been reported to lead to various types of cancer $[10,11]$ and also have been shown to be mutagenic and genotoxic by several studies [12-15].

A few studies concerning the genotoxic risks of workers occupationally exposed to coal combustion products in power plants, reported a significant increase in the level of chromosomal aberrations (CA), in acentric chromosome fragments and dicentric chromosome as well as the number of abnormal cells, sister chromatid exchanges (SCE), micronucleus (MN), and polyploid cells in workers as compared to control group $[16,17]$.

In the present study, possible genotoxic risk of workers exposed to coal combustion products in the furnace section of Afsin-Elbistan A power plant, located in South-eastern Turkey, were investigated by comet assay. Afsin-Elbistan an established in 1983 is an old power plant where the pollution control is insufficient. So, the workers were exposed to the combustion products of coal-mixture of volatile substances and also coal ash, especially in the furnace.

\section{Materials and Methods}

\section{Subjects and sampling}

A total of 36 furnace operators from Afsin-Elbistan A power plant (south-eastern Turkey) and 34 healthy male from Kahramanmaras city ( $160 \mathrm{~km}$ far from the power plant) consented to participate in the study. The workers and control group were selected after questionnaire administration for obtaining information regarding age, occupation, and years of employment, life style, and health problems, if any. The years of exposure of the workers range between 9-28 years, the mean value was $21 \pm 3.22$. The mean age of the workers was $46.46 \pm 4.77$ years (range 37-53), it was 46.06 \pm 5.81 (range 32-55) for the control group. Venous blood samples of $5 \mathrm{ml}$ were taken in heparinized tubes at the working site, codified and immediately transported at $4^{\circ} \mathrm{C}$ to the Toxicology Laboratory of Pharmacy Faculty (Gazi University, Ankara) for Comet assay.

\section{Comet assay (Single-cell gel electrophoresis-SCGE)}

The comet assay was performed under alkaline conditions using the method described previously by Sing et al. (18) with slight modification. The isolated lymphocytes (with Histopaque 1077 in phosphate buffer salin on ice) from heparinized blood samples were suspended (at $~ 2$ $\times 10^{5}$ cells $/ \mathrm{mL}$ ) were mixed with $100 \mu$ of $0.65 \%$ low-melting-point agarose in PBS at $37^{\circ} \mathrm{C}$ and rapidly pipetted onto a frosted glass microscope slide precoated with $100 \mathrm{ml}$ of $1 \%$ agarose, spread out with a coverslip and maintained at $4^{\circ} \mathrm{C}$ for 30 min to solidify. After removal of the coverslip, the slides were immersed in lysis solution $(2.5 \mathrm{M} \mathrm{NaCl}$, $100 \mathrm{mM}$ Na2EDTA, $10 \mathrm{mM}$ Tris, $\mathrm{NaOH}$ to $\mathrm{pH} 10.0$, and $1 \%$ Triton $\mathrm{X}-100$ ) for overnight at $4^{\circ} \mathrm{C}$, to remove cellular proteins. Slides were initially placed in an electrophoresis tank containing $1 \mathrm{mM} \mathrm{Na} \mathrm{ND}_{2}$ TA and $300 \mathrm{mM} \mathrm{NaOH}$, (pH 13) for $20 \mathrm{~min}$. Afterward, the tank was set at $25 \mathrm{~V}(1.6 \mathrm{~V} / \mathrm{cm}, 300 \mathrm{~mA})$ for $20 \mathrm{~min}$ at an ambient temperature of $4^{\circ} \mathrm{C}$. The slides were then washed three times for 5 min each, with Tris buffer (0.4 M Tris, $\mathrm{pH} 7.5)$, at $4^{\circ} \mathrm{C}$ before staining them with $65 \mu \mathrm{l}$ ethidium bromide (EtBr $20 \mu \mathrm{g} / \mathrm{ml})$ for analyzing. Analysis was carried

*Corresponding author: Lale Donbak, Kahramanmaras Sutçu Imam University, Science and Arts Faculty, Department of Biology, Kahramanmaras, Turkey, Tel: +90 344219 1412; Fax: +90 344219 1042; E-mail: lale@ksu.edu.tr

Received November 04, 2011; Accepted December 03, 2011; Published December 05, 2011

Citation: Kır T, Durmaz E, Ulutas OK, Cok I, Donbak L (2011) DNA hazard in Furnace Operating Workers from a Power Plant. J Carcinogene Mutagene 2:124. doi:10.4172/2157-2518.1000124

Copyright: (c) $2011 \mathrm{~K} ı$ T, et al. This is an open-access article distributed under the terms of the Creative Commons Attribution License, which permits unrestricted use, distribution, and reproduction in any medium, provided the original author and source are credited. 
out immediately after sample collection without freezing or storing. Cell viability, using trypan blue, was found to be over $95 \%$ at each time point of the study.

After the staining process, hundred cells were analysed using double slides selected randomly for examination at x200 magnification under a fluorescent microscope (Zeiss-Axioskop, Oberkochen, Germany) equipped with an excitation filter 515-560 $\mathrm{nm}$ and a $100 \mathrm{~W} \mathrm{Hg}$ lamp. DNA migration (tail intensity) was measured, using Comet Assay III image analysis system (Perceptive Instruments, UK). All slides were coded and scored blindly.

\section{Statistical analysis}

The data were analysed with SPSS 15.0 for Windows statistical programme (SPSS, Chicago, IL). Differences between control and exposed groups were evaluated by the Mann-Whitney $U$ test. Correlations between different variables were analysed by Spearmen's rho correlation test. For all statistical analyses, a level of at least 0.05 was used to determine significance.

\section{Results and Discussion}

The effects of exposing to coal combustion products in the furnace section of Afsin-Elbistan A power plant on the tail intensity selected as a marker of the genotoxic damage were presented in Table 1. Workers showed a significantly higher mean tail intensity $(9.94 \pm 2.51)$ compared to the unexposed control subjects $(8.48 \pm 2.31)(P<0.05)$.

We also analysed the data with respect to years of exposure and age of the individuals, to investigate the association between the marker and independent variables (Table 2). The results obtained from Spearman's rho correlaton analysis revealed no significant correlation between the years of exposure and tail intensity in workers $(P>0.05)$. In neither workers nor controls subjects, the incidence of markers, show a significant correlation with age $(P>0.05)$.

As compared to studies done to performed the environmental impact of energy production by coal, a few researches are available on the health risk of the workers occupationally exposed to coal combustion products in the power plants. In a study from Italy [19], malignant mesothelioma has been reported in power plant workers. In a study [20], the lung function impairment and respiratory symptoms have been reported in the power plant workers exposed to high level of coal ash. Beside, a possible lung and pleural cancer risk have been demonstrated in some studies from Italia and U.K. [21,22].

\begin{tabular}{|l|c|c|}
\hline Group & N & Tail intensity \pm SD \\
\hline Workers & 36 & $9.94 \pm 2.51^{*}$ \\
\hline Controls & 34 & $8.48 \pm 2.31$ \\
\hline${ }^{*} P<0.05$ & & \\
\hline
\end{tabular}

Table 1: The mean tail intensity in workers and controls.

\begin{tabular}{|l|c|c|c|c|}
\hline \multirow{2}{*}{ Markers } & \multicolumn{2}{|c|}{ Worker } & \multicolumn{2}{c|}{ Control } \\
\cline { 2 - 5 } & $\mathbf{r}$ & $\boldsymbol{P}$ & $\mathbf{r}$ & $\boldsymbol{P}$ \\
\hline Tail intensity & & & & \\
\hline Tail intensity vs. age & 0.305 & $>0.05$ & 0.283 & $>0.05$ \\
\hline Tail intensity vs. years of exposure & 0.269 & $>0.05$ & & \\
\hline
\end{tabular}

Table 2: Spearman's rho correlation analysis between tail intensity and independent variables.
Concerning to genotoxic risk of power plant workers, Bauman and Horvat [23] found significantly higher CA level in workers of a power station burning coal, than in control group. In another study, Leonard et al. [17], reported a significant increase in acentric chromosome fragments and dicentric chromosome as well as the number of abnormal cells in workers from coal fueled power plant as compared to control group. Beside, Celik at al. [24], reported considerably elevated CA, SCE, and MN levels in the peripheral lymphocytes of workers exposed to waste coal ash in a power plant. Moreover, the frequency of the polyploid cells was found to be significantly higher in the workers than in control subjects.

In the present study, the observed increase of DNA damage level in workers in terms of tail intensity were consistent with the previous cytogenetic studies $[17,23,24]$ reported the genotoxic risks in the workers occupationally exposed to chemical products of burning coal and ashes. Elevated level of DNA damage might originate from the many chemical compounds present in the coal ash and also in the gaseous emissions. The mixtures of these compounds may exhibit additive interactions that can not be predicted by the any single substance.

\section{Acknowledgements}

We would like to thank Research Fund of Kahramanmaras Sutcu Imam University for supporting to the study (Grant No. 2007/1-7)

\section{References}

1. Liu G, Niu Z, Van Niekerk D, Xue J, Zheng L (2008) Polycyclic aromatic hydrocarbons (PAHs) from coal combustion: emissions, analysis, and toxicology. Rev Environ Contam Toxicol 192: 1-28

2. Mastral AM, Callen MS, Garcia T (2000) Toxic organic emissions from coal combustion. Fuel Processing Tech. 67: 1-10.

3. White PA, Claxton LD (2004). Mutagens in contaminated soil: a review. Mutat Res. 567: 227-345.

4. Lewtas J (1993). Airborne carcinogens. Pharmacol Toxicol. 1: 55-63.

5. Cammarano G, Crosignani P, Berrino F, Bera G (1984) Cancer mortality among workers in a thermoelectric power plant. Scand J Work Environ Health. 10: $259-261$.

6. Band PR, Spinelli JJ, Gallagher RP, Threlfall WJ, Ng VT, et al (1990) Identification of occupational cancer risks using a population-based cancer registry, Recent Results Cancer Res. 120: 106-121.

7. Boffetta P, Jourenkova N, Gustavsson P (1997). Cancer risk from occupationa and environmental exposure to polycyclic aromatic hydrocarbons. Cancer Causes Control. 8: 444-472.

8. Bosetti C, Boffetta P, La Vecchia C (2007) Occupational exposures to polycyclic aromatic hydrocarbons, and respiratory and urinary tract cancers: a quantitative review to 2005. Ann Oncol 18: 431-446.

9. Wu J, Hou H, Ritz B, Chen Y (2010) Exposure to polycyclic aromatic hydrocarbons and missed abortion in early pregnancy in a Chinese population. Sci Total Environ 408: 2312-2318.

10. Boffetta P (2004) Epidemiology of environmental and occupational cancer Oncogene 23: 6392-6403.

11. Borm PJA (1997) Toxicity and occupational health hazards of coal fly ash (CFA). A review of data and comparison to coal mine dust. Ann Occup Hyg 41 659-676.

12. Zhong BZ, Gu ZW, Stewart J, Ong T (1995) Micronucleus formation induced by three polycyclic aromatic hydrocarbons in rat bone marrow and spleen erythrocytes following intratracheal instillation. Mutat Res 326: 147-153.

13. Andersen O (1983) Effects of coal combustion products and metal compounds on sister chromatid exchange (SCE) in a macrophagelike cell line. Environ Health Perspect 47: 239-253. 
Citation: Kır T, Durmaz E, Ulutas OK, Cok I, Donbak L (2011) DNA hazard in Furnace Operating Workers from a Power Plant. J Carcinogene Mutagene 2:124. doi:10.4172/2157-2518.1000124

Page 3 of 3

14. Öztürk S, Vatansever S, Cefle K, Palanduz S, Guler K, et al. (2002) Acute wood or coal exposure with carbon monoxide intoxication induces sister chromatid exchange. J Toxicol Clin Toxicol 40: 115-120.

15. Kuzmick DM, Mitchelmore CL, Hopkins WA, Rowe CL (2007). Effects of coal combustion residues on survival, and genotoxicity resulting from full-lifecycle exposure of grass shrimp (Palaemonetes pugio Holthius). Sci Total Environ 373: 420-430.

16. Kleinjans JC, Janssen YM, van Agen B, Hageman GJ, Schreurs JG (1989) Genotoxicity of coal fly ash, assessed in vitro in Salmonella typhimurium and human lymphocytes, and in vivo in an occupationally exposed population. Mutat Res 224: 127-134.

17. Leonard A, Deknudt G, Leonard ED, Decat G (1984) Chromosome aberrations in employees from fosil-fueled and nuclear-power plants. Mutat Res 138: 205212

18. Singh NP, Mc:Coy MT, Tice RR, Schneider EL (1988). A simple technique for quantification of low level DNA damage in individual cells. Exp Cell Res 175: 184-191
19. Crosignani P, Forastiere F, Petrelli G, Merler E, Chellini E, et al. (2001) Malignant mesothelioma in thermoelectric power plant workers in Italy. Am J Ind Med 39: 436-437.

20. Schilling CJ, Tams IP, Schilling RSF, Nevitt, C. E. Rossiter, et al. (1988) A survey into the respiratory effects of prolonged exposure to pulverised fuel ash. $\mathrm{Br} \mathrm{J}$ Ind Med 45: 810-817.

21. Forastiere F, Pupp N, Magliola E, Valesini S, Tidei F, Perucci CA (1989) Respiratory cancer mortality among workers employed in thermoelectric power plants. Scand J Work Environ Health 15: 383-386.

22. Nichols L, Sorahan T (2005) Mortality of UK electricity generation and transmission workers, 1973-2002. Occup Med (Lond) 55: 541-548.

23. Bauman A, Horvat $D$ (1981) The impact of natural radioactivity from a coal fired power plant. Sci Total Environ $17: 75-81$.

24. Celik M, Donbak L, Unal F, Yuzbasıoglu D, Aksoy H, et al. (2007) Cytogenetic damage in workers from a coal-fired power plant. Mutat Res 627: 158-163. 